DOUTRINA

\title{
Assistência prisional e post-prisional
}

\author{
Eduardo Correia \\ Catedrático de direito criminal na Faculdade \\ de Direito de Coimbra. - Vogal do (Conselho \\ do Instituto de Criminologia de Coimbra. \\ Superior dos Servicos Criminais. - Diretor
}

1 - Como é sabido, os sistemas punitivos anteriores: aos fins dos séculos XVIII ou XIX eram, fundamentalmente, estruturados sôbre as penas corporais (v.g., pena de morte, mutilações, açoites, tormentos) e infamantes (v.g., marca de ferro em braza, baraço e pregão, exposição no pelourinho), a que, em certos países, se juntavam as galés, o destêrro ou degrêdo e as penas pecuniárias.

Certo que não falta, ainda, nesse período, a própria prisão nas cadeias, troncos ou cárceres.

Simplesmente - e esta nota é essencial - tal pena. tinha então caráter de todo em todo excepcional.

Tirando, na verdade, o caso da chamada prisão preventiva, ou seja, da detenção do criminoso até o julgamento, pondo de parte, ainda, a chamada detenção coercitiva, visando forçar o condenado em penas pecuniárias a solvê-las; a prisão com caráter repressivo, concebida como sanção, raras vêzes é utilizada e, quando tal sucede, limita-se a puro sofrimento resultante da privação de liberdade por vêzes agravado com ferros, tormentos ou trabalhos força- 
dos e regra muito geral com duração curta; dias e, quando muito, meses.

2 - Ora bem: fruto de evolução mais ou menos lenta e isolada, certo é que êste estado de coisas se modifica e, nos fins do século XVIII e XIX, a prisão com caráter repressivo, como verdadeira pena, de excepcional, eleva-se a fulcro, transforma-se em reação se não exclusiva pelo menos predominante nos sistemas repressivos criminais.

$\mathrm{E}$ tal fato, que é das características mais salientes do direito criminal moderno, foi a necessária conseqüência do movimento iluminista que, por tôda a parte, impusera a abolição das penas corporais e diretamente infamantes. (1)

Amputando-se, com efeito, desta forma e na sua essência, o sistema repressivo da época, e sendo forçoso preencher a lacuna tão vasta que daí resultava, a pena de prisão apresentava-se como meio para tal mais recomendado tantas esperanças os Howard, os Penn, etc. nela punham e ei-la transformada como que em panacéia de efeitos milagrosos para todos os criminosos e para todos os crimes, e ei-la elevada a fulcro sôbre que se moviam os sistemas punitivos de todos os projetos de Códigos penais dos fins do século XVIII e XIX.

3 - Na medida em que se não queria, porém, dar-lhe o sentido de um puro sofrimento que a transformaria, ao fim e ao cabo, numa pura pena corporal, mas antes pretendia atribuir-se-lhe também a função de regeneração e de readaptação do criminoso à vida social a conseguir em primeira linha através do trabalho, como ensinava a tradição das Zuchthäuser holandesas (2) abriam-se à ciência e política penitenciária os mais complexos problemas.

(1) Cfr. Kriegsmann, Einführung in die Gefängniskunde, pág. 8 e segs.

(2) Sôbre as relações da prisão com as célebres Zuchthaüser de Amesterdão, vid. Von Hippex, Beitrage z. Geschischte d. Freiheitsstrafe in Zeit f. d. g. Strafr., ano XVIII, pág. 417 e ainda Eberhard Schmid, Revue Pénale Suisse, 1947, pág. 172 e segs. 
Pois, logo no que toca à sua execução intra-muros, além de tudo o mais, oscilava-se entre o Sila de um isolamento celular completo que dificultava a utilização do trabalho como meio regenerador, envolvia inconvenientes relativos à saúde física e mental dos condenados, além de tornar quase impossível a sua preparação para a vida comunitária livre e o Caribedes de uma vida em comum dos presos, implicando a possibilidade do contágio dos melhores pelos piores e de assim transformar os estabelecimentos prisionais em verdadeiras escolas do crime dilema de perigos que os chamados sistemas progressivo e irlandês procuraram vencer sem lograr, contudo, completo êxito.

Por outro lado, a prisão, segregando o criminoso da vida social e marcando-o com o ferrete da infâmia que lhe anda ligada, mesmo depois de cumprida, não só importava ou podia importar um desequilíbrio no meio social familiar de onde o delinqüente é retirado, altamente favorecedor da criminalidade, como dificulta a própria regeneração e possibilidade de readaptação à vida social honesta e livre do ex-recluso.

4 - E tais considerações, caricaturadas por certos criminalistas, levam-nos a negar à pena de prisão qualquer papel reeducador, assacando-lhe antes um efeito criminógeno que o aumento sempre crescente da reincidência, aliás, parece confirmar.

Daí o seu sorriso céptico ante as tentativas da solução dêste problema da reincidência, através de uma agravação ou prorrogação das penas privativas de liberdade, o que só significaria querer remediar o mal reforçando justamente uma das causas mais importantes dêsse mal.

$\mathrm{E}$, eis, porque, levantada a questão já na Alemanha, em 1802, num belo estudo, só recentemente publicado, (3)

(3) Warum werden so wenig Strafälingue in Zuchthaus gebessert? - (Porquê se corrigem tão poucos criminosos na cađeia?). Verlag: Hamburgische Strafanstalten, 1924. 
vozes repetidas como as de Mittelstädt (4), Bruck (5) e modernamente Seelig (6), Ataliba Nogueira, (7) etc. proclamam a total falência da pena de prisão e a necessidade de a abolir.

5 - Quê dizer de tudo isto?

Pois que a moderna política criminal não deixa de convir, como melhor veremos, na necessidade de diminuir, tanto quanto possível, o âmbito de aplicação das penas privativas de liberdade:-- "despovoai as prisões" é slogan (8) que, cada vez, conquista mais adeptos.

Simplesmente, não se pode negar que, em muitos casos, e em último têrmo, é forçoso lançar mão da pena de prisão. Em todo o caso, concede-se que importa renovar inteiramente, não só as concepções sôbre a sua execução intra-muros ou institucional, como reponderar o problema das relações do criminoso com o mundo exterior, de onde saiu e para onde normalmente há de regressar.

Não tendo que tratar aqui do primeiro aspecto, procuremos analisar mais detidamente o segundo, que constitui, pelo menos em parte, justamente o têma dêste nosso Relatório: assistência prisional e post-prisional.

A entrada do delinqüente na cadeia, a fim de cumprir a pena que foi condenado, tem as mais vastas conseqüểncias no mundo externo. (9)

(4) Gegen die Freiheitsstrafen - (Contra a pena de prisão), 1879.

(5) Fort mit den Suchthäusern - (Ponha-se fim à pena de prisão), 1894.

(6) Kriminologie

(7) Pena sem prisão, 1938.

(8) Deve-se a Schlyter, cfr. Simson, Bedingte Verurteilung, in Zeitschrift für die gesamte Strafrechtswissenschaft, 1952, pág. 140.

(9) Sôbre o que a seguir se escreve, cfr. Brandstatter, Entlas. senenbehandlung und fürsorge in Handwöterbuch der Kriminologie, 
1 - Entre elas coloca-se desde logo a destruição do equilibrio da unidade institucional ou da família a que o réu pertence, o que é susceptível de se projetar no plano econômico, espiritual, social e até biológico ou sanitário.

a) Basta pensar como tal desiquilíbrio pode implicar a perda de direção de negócios, a impossibilidade de continuar a assegurar a manutenção de seguros sociais, a perda do emprêgo e até - o que é o mais - o desaparecimento do único meio de sustentação e de apôio moral e econômico da família.

A isto acresce que, com freqüências, as despesas da defesa, a indenização ao ofendido, os impostos de justiça e multas a satisfazer impõem a venda de bens que existam, ou a contrair dívidas que mal se vê como hão de vir a ser solvidas é, porventura, a total ruina econômica do respectivo agregado familiar.

b) Aos males que daí diretamente advém para a família, às preocupações que tal há de normalmente criar ao recluso juntem-se as ligadas ao efeito moral e social da condenação: eis ali a mulher, o pai, os filhos, os irmãos de um homicida ou de um ladrão. E, sem mais, numa comunicação do pecado e do crime que transcende os limites da responsabilidade individual, a sociedade mais ou menos conscientemente, evita-os, degrada-os, humilha-os.

c) Depois, carecida de apôio econômico e de direção moral, a educação dos filhos periga, a mulher, se nova, é tentada pelas suas fraquezas e é o adultério se não a prostituição.

d) Na precária situação econômica e moral em que se pode vir a encontrar, fica ainda em risco a própria saúde da família inteira.

2 - E tudo isto tem a maior importância do ponto de vista do direito criminal.

vol. I, pág. 276 e segs.; o referido estudo em nota 2 e GrohmanN, Die fittliche und soziale Hebung Verbrecherischer, in Zeitschrift für die gesamte Strafrechtswissenschaft, vol. 46, pág. 374. 
a) Pois é êsse ambiente, já de si criminógeno, que há de receber, no dia da libertação, o condenado. E degradada, humilhada, decaída, não poderá essa família tonificar o desejo, porventura honesto e sério do ex-recluso, de se readaptar. E eis aí criada uma poderosa causa de reincidência.

b) Por outro lado, ainda durante o cumprimento da pena, a idéia de que a família virá a sofrer pelo seu crime, sem culpa, a preocupação sôbre o destino dos seus haveres, pela sorte dos filhos, pela honra da mulher, transformará, acaso, em revolta o espírito de conformação de que estivesse animado o recluso, permitindo uma prognose carregada de futuras atividades criminosas.

c) A segregação da vida social, que a entrada na prisão envolve, reflete-se, além disso, diretamente na própria personalidade do criminoso. Com efeito, integrado na comunidade artificial, porque imposta da cadeia, o prêso amolece os seus sentimentos de sociabilidade; deixa de receber o influxo salutar da vida livre e das suas concepções morais e sociais; quebra os laços de contacto com os amigos, os parentes, as instituições profissionais ou de outra ordem a que tivesse pertencido o que tudo, seguramente, lhe rouba um forte estímulo e apôio para fortalecer a sua vontade de se regenerar e readaptar socialmente.

3 - E com isto fica sumariada uma série de problemas que seguramente se impõem à consideração de quem queira estudar a pena de prisão nas suas relações com a vida livre, logo durante a fase da sua execução.

$O$ recluso sairá porém, um dia, da cadeia presumidamente animado do melhor desejo de não voltar ao crime.

a) Mas quem é êsse recluso que vai retomar a liberdade, que vai procurar reintegrar-se na sociedade?

Um homem que viveu, talvez dezenas de anos, na prisão, ou seja, numa comunidade de vida em que se perdeu quase tôda a livre iniciativa; em que tudo o que se refere a problema relativos a alimentação, vestuário, leituras, em 
suma, em que pràticamente tudo o que se faz está regulado e predeterminado; em que se torna impossivel ou difícil dedicar livremente a atenção a problemas ou atividades por que se tenha particular preferência; en que se perdeu ou diminuiu, portanto, o sentimento de auto-modelação da vida e da responsabilidade perante o dever de assegurar a satisfação das necessidades que a vida impõe a cada um; em que a maturidade para se adaptar às respectivas exigências está muito longe de significar maturidade para viver na vida social livre e inteiramente entregue a si próprio na resolução de todos os problemas que esta lhe impõe; em que domina a coação, a disciplina, a autoridade que se não. escolhe, mas a que, quando muito, se adere por razões de conveniência.

b) Mas não só isso: esta coação externa que constitui a disciplina dos estabelecimentos prisionais, reduzindo-Ihe quase a zero a liberdade, faz-lhe, decerto, aspirar ardentemente pelo momento de a reobter.

$O$ recluso vê o momento da libertação com um oti-mismo que excede em muito o que realmente a vida pode oferecer e em especial of erece aos que passam pela cadeia.

Daí tôda uma série de desilusões e decepções, que re-voltam, deprimem e anulam tôda a vontade de manter o voto e a promessa de se transformar em cidadão honesto.

4 - Efetivamente, que lhe reserva a sociedade, como. irá ela tratar aquêle para quem, cumprida a pena, se abrem as portas da prisão?

A cada passo, e desde logo, com a suspeição de todos os crimes e atos censuráveis que se venham a praticar. Depois com um repúdio e com uma segregação mais ou menos completa e desapiedada.

Essa sociedade que na sua maioria "vê na prisão uma espécie de apodrecedor, situado como depósito de lixo ou imundicie, na periferia das cidades onde a vida social resguardando-os dos olhares honestos amontoa os seus. 
dejetos, ai os deixando decompor lentamente" (10) essa mesma sociedade, quando o recluso um dia é pôsto em liberdade, continua a procurar evitá-lo, afasta-o do seu contacto, recusa-lhe todo o apôio, receosa de que êle lhe transmita a infâmia que o macula.

a) E, assim, são muitas vêzes os próprios parentes próximos do condenado, se não decaídos já na miséria e na degradação econômica, moral e social, que receiam o momento em que o recluso será liberto e, quando êle chega, o repudiam.

Os próprios pais e mães não têm por vêzes piedade dos filhos ou filhas transviadas, expulsando-os e não os recebendo nos seus lares.

$\mathrm{E}$ que haverá que esperar dos estranhos?

b) $\mathrm{O}$ antigo ciclo de relações sociais, profissionais repudiam, normalmente, um ex-recluso: o próprio sentimento de honra e dignidade impede-os de acamaradar e estreitar relações de amizade com um homem infamado pelo seu crime e, sobretudo, pela prisão sofrida. Por outro lado, se o aceitam, a cada passo e a propósito dos mais pequenos erros o censuram e the fazem lembrar o seu passado.

Em face disto o criminoso, que, cumprida a pena "pagara à sociedade a sua dívida", sente-se vitima de uma injustiça cruel. Espicaçado no seu sentimento de culpa, não poderá deixar de adensar o seu complexo de inferioridade, que o diminui, e lhe rouba tôda a confiança em si próprio. $\mathrm{E}$, irresistivelmente, há de vir-lhe ao espírito a vida na cadeia, sem liberdade, mas também sem todo êste calvário. Como um indomável complexo de compensação lhe ensinará ou, porventura, lhe imporá, de novo, a estrada do crime.

5 - A tudo isto acresce ainda que, evitado, molestado, pela sociedade, amarrado a uma infâmia que não está nas suas mãos e melhor boa vontade poder apagar, êle, nem

(10) LuIsifR, La prison est elle un facteur criminogène? in Revue Pénale Suisse, 1952, pág. 111. 
sequer estará, acaso, em condições de ganhar a sua vida por si, se é velho, doente ou frágil para qualquer trabalho.

$\mathrm{E}$, então, mais prementemente se lhe mostra, como única alternativa, a degradação da mendicidade com o seu cortejo de tentações e de novos crimes, que, afim ao cabo, the trazem de novo. . a paz e a segurança da cadeia.

a) Mas ainda quando apto para trabalhar, as perspectivas de reintegrar na sociedade, não se mostram, as mais das vêzes, muito favoráveis.

É que a vontade honesta de procurar emprêgo e de ganhar o sustento para si e para a família, quebra-se, com freqüência ante a resistência da sociedade em dar-lho.

E, assim, logo o Estado, em face do seu registo criminal, se nega a colocá-lo ou retomá-lo nos seus quadros.

E haverá mais que pretender do lado dos particulares?

Instintivamente, a maior parte dêles, seguindo, aliás, o exemplo do próprio Estado, recusa-se a admitir ao seu serviço, aquêle, que sabem, foi ladrão, homicida ou brigão.

Poucos quererão suportar o risco. de colocar no seu escritório, nas suas oficinas, nos seus campos, em suma, de dar trabalho a quem, um dia, praticou um crime e continua, porventura, a ser perigoso.

Por outro lado, para além do perigo que, nesse caso, dar trabalho envolve, há ainda, por assim dizer, a tendência para não prestar solidariedade ao que pecou, para evitar, afastar de si, a infâmia que o acompanha.

E quando alguém, mais esclarecido, esteja disposto a conceder-lhe emprêgo, adaptar-se-á êle e a respectiva remuneração às possibilidades e legítimas pretensões do ex-recluso? Que espécie de trabalho deve ser dado a quem tem, por exemplo, um curso superior, que já não pode exercer, a quem foi negociante ou é especializado em atividades de cujo exercício foi interdito?

$\mathrm{E}$ quem há de fornecer os instrumentos de trabalho e o vestuário que lhe permitam exercer decentemente o seu ofício? 
Depois não basta a boa vontade de quem concede emprêgo. Há ainda que contar com a repugnância dos outros trabalhadores, operários ou assalariados, em terem como colega ou companheiro, um antigo prêso.

Há ainda que não esquecer as próprias emulaçôes e invejas contra um ex-recluso que, mercê da sua habilidade e especiais dotes, se destaque e distinga dos seus companheiros. E não poderão então evitar-se as censuras, os doestos e as insinuações cruéis e maldosas ao seu passado.

Dai que seja muitas vêzes quase impossível que o liberto encontre, só por si, trabalho estável e harmônico com as suas legítimas espectativas.

b) $\mathrm{E}$ isto traz-lhe o mais angustioso dos problemas. É que, alcançada a tão ansiada liberdade, êle não consegue afinal prover ao seu sustento, não alcança sequer meios para ter um tecto onde se abrigue.

E se tem família as conseqüências do desemprêgo são acaso ainda piores. De fato contando ingênuamente que o regresso do chefe lhe traga a possibilidade de solver dividas contraídas, de garantir o seu amparo e o seu sustento, o agregado familiar dá-se conta de que, em vez de almejado benefício, está colocado em face de mais um encargo com que é mister arcar. E chovem as censuras, as recriminações. A própria alegria de alcançar a liberdade se destrói, na alma do recluso, pela humilhação e pela dor, de se ver incapaz de prover às suas necessidades e às dos seus. $\mathrm{E}$ daí à revolta, ao desespêro, a novo crime, é só um passo.

Até porque a resistência da sociedade em lhe dar trabalho pode destruir e destrói, normalmente, o desejo sério de regeneração. Na maior parte dos casos, faz mesmo perder os hábitos de trabalho adquiridos, que são a condição de uma efetiva readaptação social. A experiência mostra, de resto, que o liberto que não encontre, imediatamente, trabalho à saída da prisão, cai na ociosidade que constitui um fator decisivo na etiologia de novos crimes.

6 - E pouco vale que o recluso traga da cadeia o seu pecúlio. Pois desabituado de se reger a si próprio e aos 
seus bens, a breve trecho o esbanja na satisfação de necessidades supérfluas, quando não no alcoolismo e na prostituição.

E, depressa, encontra-se sem meios, sem trabalho, porventura doente; acossado e repudiado pela sociedade; refugiando-se nas mais baixás camadas sociais; procurando antigos companheiros de prisão, solidários com êle na mesma desonra, revoltados como êle, pela mesma injustiça com que o mundo os trata; pronto a deixar-se dominar pelos mais perversos; sem inibições perante as menores solicitações para o crime; e, até, supra-compensando-se, psicològicamente, pela sua prática. Quer dizer: estão criadas as condições ótimas para a reincidência, mesmo daqueles que, algum dia, acalentaram o desejo e formaram a vontade séria de se regenerarem e de viverem honestamente na sociedade de homens livres.

7 - A isto junte-se o pessimismo de muitos sôbre a capacidade que tem o modo como é executada a pena de prisão, para estimular e desenvolver essa vontade de readaptação social. Acrescente-se, ainda, a convicção de que ela constitui mesmo um fator criminógeno, na medida $\mathrm{em}$ que a vida nos estabelecimentos prisionais aumenta a perversidade dos já naturalmente perigosos e contamina os endògenamente bem dotados. $\mathrm{E}$ logo todos compreenderão o que há de razoável no pensamento daqueles criminalistas que, como dissemos, apregoam a total falência das penas privativas de liberdade e propõem a sua abolição.

\section{III}

1 - A verdade, porém, é que, se, como foi referido, não é possível negar, pelo menos uma grave crise da pena de prisão, a verdade é que também se não vê maneira de, por agora, integralmente a substituir por outro meio repressivo ou preventivo. 
Por outro lado, as críticas apontadas não tomam em consideração as virtualidades de melhorar a sua execução intra-muros, como não atendem às instituições complementares que, sem remover completamente os seus defeitos e possíveis perigos, contudo, grandemente os podem diminuir ou atenuar.

a) Efetivamente, para além dos progressos realizados relativamente ao próprio aspecto institucional das penas privativas de liberdade, desde cedo houve quem se desse conta de que o recluso, enquanto cumpre a sua pena, como ainda no momento que é pôsto em liberdade, é um ser humano, em especial estado de necessidade, carecido de auxílio e amparo alheio.

Como imperativo cristão de caridade, ou simples dever de solidariedade humana, aí está a lição das Misericórdias, de tantas ordens religiosas ou associações laicas, a olharem o criminoso, para além de culpado, como alguém a quem se deve auxílio e apôio.

E não poderá neste domínio deixar de se recordar o exemplo de figuras como S. Vicente de Paulo assistindo e fundando um hospital para os condenados às galés, como não pode deixar de ter-se uma palavra de lembrança e homenagem para o movimento que mais tarde na América e na Inglaterra nesse sentido foi levado a cabo pelos Quaqueres e por essa heróica mulher que foi Elizabeth Fry.

2 - O têma, foi tomado, até, pela própria arte e literatura.

A quem não ocorre o impressivo libelo de Vítor Hugo contra o mundo que torna impossivel a vida honesta a êsses "miseráveis" que são os "Jeans Valgeans" saidos da prisão?

Quem não sentirá a beleza e o rigor do pensamento de Oscar Wilde no seu trágico "De profundis" ao escrever: "muitos homens depois de libertados, levam a prisão consigo no ar e no ambiente que os rodeiam, escondem-no no âmago do seu coração, como uma desgraça secreta, e, por fim, como pobres criaturas para sempre envenenadas, pro- 
curam um buraco sombrio para morrer. É doloroso que êles se vejam reduzidos a isso e é uma injustiça, uma terrível injustiça que a sociedade a tanto os force. Esta arroga-se o direito de inflingir aos homens castigos terríveis, mas enferma do supremo vício da superficialidade se não compreende o que fêz. Quando o têrmo da pena chega a sociedade entrega o ex-recluso a si próprio, quer dizer, abandona-o, no preciso momento em que começa o seu maior dever para com êle. Realmente envergonhada da sua própria ação, foge daquele que castigou, como se evita um credor que se não pode reembolsar, ou se evita àquele a quem se provocou uma sorte irreparável e irremediável. Por meu lado posso pretender que, se compreendo o que tenho sofrido, a sociedade deve ter consciência do castigo que me inflingiu, de maneira que não haja amargura, nem ódios de lado a lado?"

3 - Mas o imperativo, que impõe auxílio e apôio aos que, tendo embora prevaricado e merecido castigo, não deixam, contudo, de ser homens em particular estado de necessidade, não é só têma literário impõs-se à realidade da vida, fêz arregimentar vontades e energias privadas: organizou-se.

Assim, já no fim do século XVIII, se criam na América sociedades (11) interessadas pela vida prisional e pela sorte dos que dela saem.

E elas desenvolvem-se, ali e noutros países, largamente, no século XIX tendo, entre os seus fins, reunir esforços privados para acudir e assistir aos presos e ex-reclusos, isto é, realizar o chamado Patronato das Prisões (12).

(11) Philadelphia Society for Alleviating the Miseries of Public Prisons, 1787, anteriormente conhecida por Philadelphia Society for the Relief of Distressed Prisoners; Prison Association. New York, 1846.

(12) Na França denomina-se "Patronage", nos países anglosaxônicos "After care ou aid for discharged prisioners" e, na Alemanha "Fürsorge für gefangene und Entlassen" ou, mais simplesmente "Bewährungehilfe". 
Êste propõe-se, com efeito, remover os males e as conseqüências criminógenas ligadas ao problema das relações do prêso com a vida exterior, quer durante a reclusão, quer no momento em que é pôsto em liberdade e que se desdobram numa atividade de natureza moral, econômica, e sanitária (13).

A) E assim, ainda durante o periodo de privação da liberdade, êle procura promover a defesa da dignidade moral da família, de onde saiu o recluso.

a) $\mathbf{A}$ isto se deve juntar um auxílio econômico, quer destinado a garantir o mínimo de subsistência e educação aos filhos, quer visando impedir a ruína da exploração econômica que era dirigida pelo recluso, a perda definitıva do seu emiprêgo, dos seus seguros sociais, etc. .

Neste mesmo quadro se integra ainda, além da defesa da honra da mulher, a sua própria preparação para levar a cabo o cumprimento dos deveres que sôbre ela agora impendem, para compreender a situação criada e ainda para aceitar e criar o ambiente próprio ao marido, quando êste, cumprida a pena regresse ao lar.

Igualmente se impõe neste periodo uma assistência médico-social tendente a prevenir as doenças e degenerescência no respectivo agregado familiar.

b) Por outro lado, importa manter durante a reclusão, e na medida do possivel, o contato do prêso com os problemas do mundo exterior.

$\mathrm{E}$ aqui há a considerar as visitas e correspondência do detido com a sociedade livre, especialmente com os seus familiares e pessoas que lhe são caras.

Em casos especiais de doenças graves, morte de parentes próximos ou, na última fase da detenção, porven-

(13) Cfr. Mittermaier, Gefängniskunde, 1954, pág. 145, SeyFARTH, Fürsorge für Gefangene und Entlassene in BumkE, Deutsche Gefängniswesen, pág. 434. Sôbre o fim do Patronato ver ainda Le patronage des détenus libérés in Recueil de Documents en matière Pénale et Pénitentiaire, vol. X, pág. 185. 
tura como meio de conseguir trabalho, depois de cumprida a pena, pode pôr-se o problema, ainda, da saída por algumas horas ou dias do prêso.

Se, porém, êste aspecto está, naturalmente, ligado a questões de disciplina interna (14), o primeiro deve considerar-se como um dos mais importantes problemas do Patronato.

Importa, na verdade, estimular as visitas da mulher, dos filhos, dos parentes, dos amigos que estejam ligados ao ambiente familiar do recluso e que tonifiquem o seu desejo de voltar para junto dêles e, acaso, de os apoiar. $O$ visitador falando-lhe dos seus antigos interêsses pela vida real, da sua familia, recordando-lhe a vida do exterior, a vida real, lembra-lhe implicitamente os deveres que não cumpriu, facilitando assim a sua regeneração.

c) Mas, a par disso e como particular problema, impõe-se ganhar a confiança do prêso, quebrar a barreira que êle opõe em dar sèriamente conta dos seus problemas, estimulando-lhe o interêsse e a vontade de reintegrar-se na sociedade.

E êste é dos mais delicados, melindrosos e complexos aspectos da assistência aos presos.

Pois não se trata de lhes prometer uma vida fácil fora da cadeia, que só lhe criaria ilusões e falso otimismo. É mister fazer compreender ao recluso as dificuldades de tôda a ordem que a vida lhe vai oferecer, mas a um tempo robustecê-lo na crença de que é possível vencê-las mercê da sua vontade e do apôio que lhe dará o Patronato.

Certo que isso não poderá fazer-se arbitrária e desordenadamente. Impõe-se respeitar até onde fôr necessário as regras e disciplina penitenciária, evitar conflitos de influência e de autoridade, como importa selecionar os visitadores consoante a sua intenção e os seus planos, evitando

(14) Cfr. para o direito francês Pinatel, Traité élémentaire de science Pénitentiaire et de Défense Sociale, pág. 353. 
tudo o que, em vez de benefícios, seja pretexto para se levarem a cabo correspondência ou contatos interditos ou até para facilitar evasões.

B) Há depois que considerar o momento em que o recluso é pôșto em liberdade. Cumprida a pena, paga a sua divida ao Estado, vai na verdade o ex recluso retomar o seu lugar na vida livre, porventura, animado de vontade séria de nela se reintegrar.

a) Mas o êxito dessa readaptação está em parte condicionado pela obra de preparação geral levada a cabo e por aquilo que, nesse momento crítico de libertação e a seguir, se faça, no sentido de lhe criar ambiente, de o apoiar e de o auxiliar.

Assim, antes de tudo, estará tal êxito dependente do que em geral se realizou, mostrando à sociedade como the importa vencer os seus respeitos humanos e falsos prejuízos, recebendo com espírito de compreensão aquêle que, tendo pago a sua dívida à sociedade, não deverá ser por ela repudiado, humilhado ou explorado.

Pois é certo que a infâmia social que definitivamente se faça pesar sôbre aquêles que um dia praticou um crime é, porventura, um fator inibidor da criminalidade.

Só que mal vai à sociedade que faça assentar a sua defesa na injustiça que é exigir mais do que aquilo que lhe deve o criminoso, ou seja, o cumprimento da pena a que foi condenado, e na falta de caridade e humanidade que constitui não dar uma nova oportunidade ao homem que uma vez decaiu, sabe Deus por que motivos, de realizar a sua legítima aspiração de retomar na sociedade o lugar que a sua falta, já expiada, lhe fêz perder.

Aliás — e isto é decisivo - se uma atitude contrária da sociedade do ponto de vista da prevenção da criminalidade primária pudesse julgar-se útil, ela constituiria e eis aí uma curiosa antinomia do direito criminal a mais forte 
alavanca para a reincidência e, portanto, condenável dum ponto de vista preventivo (15).

b) Mas o êxito da reintegração do libertado está ainda dependente do que se fêz mais diretamente no âmbito da família ou comunidade para onde o recluso regressa, da confiança que se conseguiu alcançar sôbre êle, do que se fêz no esclarecimento do seu complexo de culpa, da medida em que se robusteceu a sua vontade e energia moral, do que se obteve na sua preparação profissional e para as dificuldades da vida e ainda na defesa da sua saúde e capacidade para o trabalho.

c) Mas, no preciso momento da libertação e no período que se lhe segue, importa, ainda, pôr tudo isso à prova desenvolvendo, consolidando e fazendo frutificar o apôio moral e sanitário em que se esgota a função do Patronato.

$\mathrm{E}$ é assim que se torna necessário garantir-lhe assistência na doença, na velhice, na invalidez.

Como é mister, discreta mas eficazmente, fortalecer-lhe a vontade de readaptação, ajudando-o a resolver as crises morais por que passe, facilitando-lhe, se é solteiro, a constituição de um lar, e defendendo-o das múltiplas tentações da vida.

C) Por seu lado, há que proporcionar-lhe apôio em todos os seus problemas econômicos e, fundamentalmente, conseguir-lhe trabalho.

Assim, se o ex-recluso acumulou um pecúlio na prisão torna-se necessário evitar o seu esbanjamento ou aplicação pródiga e irrefletida.

Se conseguir, por si só, emprêgo, será, porventura, mister vesti-lo decentemente ou fornecer-lhe os necessários instrumentos de trabalho.

(15) Cfr. ExNer, Criminologia, trad. espanhola, pág. 167. 
Inadiàvelmente, torna-se, porém, imperioso garantir-lhe tecto e sustento.

E não basta ùtilmente para tal conceder-lhe um subsídio (16) que durante algum tempo resolva êsse problema. Importa dar-lhe, se pelos seus próprios meios o não alcançou, emprêgo estável.

$\mathrm{E}$ isso não só para que êle assim tenha um meio permanente de prover às suas necessidades e às da família que lhe cumpre sustentar, mas porque só de tal forma se pode ter esperança de que não perca os hábitos de diligência que adquiriu e de que se afaste o perigo de que a ociosidade e as conseqüências sociais e morais degradantes que lhe andam ligadas o não arrastem de novo para o crime.

$\mathrm{E}$ eis porque todos recomendam que o trabalho deva ser imediato à libertação, sem permitir soluções de continuidade e, portanto, sem qualquer espécie de intervalo ou férias.

Simplesmente, tal só será possível, se a ocupação do recluso estiver já garantida antes da sua saída da prisão (17).

Ora, não será tarefa fácil a missão de a encontrar. Com efeito, como se disse, sobretudo em períodos de crise, o desemprêgo abrange os próprios trabalhadores sem antecedentes criminais e, na concorrência, só com muita dificuldade o gerente de uma emprêsa dará preferência a um ex-recluso.

D) Depois não basta encontrar trabalho. É mister procurá-lo em condições de êle se harmonizar com as le-

(16) Grünhut, Penal reform, pág. 322 e Fox, The English Prison and Borstal Systems, pág. 254; cfr. ainda Report of the Departmental Committee on the Employment of Prisoners, Parte II, Employment on Discharge, 1935, passim.

(17) Cfr. nota anterior. 
gítimas pretensões do ex-recluso, com a sua cultura e a sua especialização. É o caso por exemplo de encontrar ocupação para um ex-magistrado, um ex-advogado, médico ou funcionário.

Acresce, por outro lado, que a recuperação social conseguida através do trabalho só é eficaz se não fôr prejudicada pelo ambiente do lugar em que mora ou passa as suas horas de ócio o ex-recluso.

$\mathrm{Na}$ verdade dada a dificuldade de, sobretudo nas cidades, se encontrar habitação e alimento, que se harmonizem com o salário normal a que pode aspirar um ex-recluso, aquêles que não têm família, ou que convém que a ela não regressem, podem ser forçados a viver em zonas onde a promiscuidade, as tentações e os contactos com as camadas em particular perigo moral favoreçam especialmente a reincidência.

Além de encontrar trabalho, é, pois, ainda, necessário evitar êste perigo.

Simplesmente nem sempre é possível dar a tais problemas uma solução imediata nos quadros normais da sociedade.

Daí a idéia concebida há muito tempo de organizarem Homes, casas, lares, refúgios, escritórios ou colônias de trabalho para os ex-reclusos, com meios de transição, com pontos de passagem para a sua total reintegração na vida social espontânea (18).

(18) Sôbre o problema cfr. SiEverts, Übergangsheime für entlassene Strafgefangene in Zeitschrift für die Gesamte Strafrechtswissenschaft, vol. 55, pág. 307 e segs.; actes du Congrès Pénitentiaire International de Rome, 1885, tomo I, págs. 471 a 487, 490 a 506 e 608 a 618 e Actes du Congrés Pénitentiaire International de Berlin, 1935, vol. I, págs, 281 a 312 e vol. IV, págs. 219 e segs.; e ainda StARKE, Gefangenen- und Entlassenenfürsorge, in Reform des Strafvollzuges dirigida por Frede e Grünhut, pág. 226 e Mittermaier, ob. cit., pág. 147. 
a) A criação dêstes lares ou colônias de trabalho e transição não deixou, porém, de ser objeto de muitas críticas, como de muitos elogios e estímulos.

E tal é a importância do problema que êle figurou no programa do Congresso Penitenciário Internacional de Roma em 1885, voltando a ser um dos têmas do de Berlim de 1935 ( $3 .^{a}$ Seção).

$\mathrm{E}$ é curioso que, enquanto o Congresso de Roma, na Seção respectiva, votou a necessidade da criação de tais Homes, vindo tal resolução a ser condenada pela Assembléia do Congresso, no de Berlim, a despeito do Relator manifestar um ponto de vista contrário, não deixou de se tomar a resolução final de que "a criação de Homes de transição para presos postos em liberdade não é sòmente desejável, mas necessária" (19).

b) Certo é, todavia, que continua a haver quem reaja contra a organização de tais casas de transição.

É que elas envolveriam o perigo de uma corrupção recíproca dos internados, e de se transformarem assim em verdadeiras sedes de associações ou escolas de malfeitores.

Êsse perigo de contágio seria tanto maior quanto é certo que o ex-recluso sai do estabelecimento prisional de uma separação celular, pelo menos noturna, para um contacto livre entre indivíduos, porventura, não inteiramente regenerados.

Por outro lado, justamente os efetivamente corrigidos não quererão utilizar tais Homes, sentindo-se rodeados por indivíduos perigosos que só comprometeriam.

Os Homes e as colônias de trabalho trariam ainda, no caso de desemprêgo, um benefício para os indivíduos com antecedentes criminais em prejuízo dos empregados honestos.

$\mathrm{E}$, finalmente, não se livrariam da suspeita da polícia que os considerariam centros de receptação.

(19) Cfr. nota anterior. 
Condenando assim os Homes de transição, propunha-se a colocação dos ex-reclusos que não tivessem lar próprio junto de familias que os quisessem receber ou o seu internamento nas instituições, que existam em geral, destinadas a receber os desempregados e os sem abrigo.

Parece-nos, porém, que tôda a argumentação referida não atende às realidades (20).

Efetivamente o perigo de contágio entre individuos com antecedentes criminais começa logo na prisão. E ninguém, hoje, pretende que, pelo menos no que toca ao trabalho, se exclua uma certa comunidade de presos.

O fato de, com freqüência, sairem da cadeia delinqüentes não regenerados só significa que se deve executar melhor a pena de prisão e que se impõe um condicionalismo mais rigoroso na libertação definitiva dos presos.

Negando-se aos ex-condenados trabalhos e abrigo nas casas de transição, não se evita que êles contactem fora delas, nas piores condições de perigosidade, carecidos de trabalho e de abrigo e, ainda, sem a supervisão do Patronato ou Assistência.

A sociedade e a polícia pensará dêsses Homes o que resultar, justamente, das provas que tenham dado e que possam vir a dar.

Por seu lado, a crítica resultante de se beneficiarem ex-reclusos em prejuízo de desempregados sem antecedentes criminais, não toma em consideração que os criminosos postos em liberdade sofrem de um particular estado de necessidade, já que, além do mais, lutam contra a barreira que a sociedade opõe à sua vontade de nela se reintegrar.

A isto acresce que o apoio dado em tais Homes não visa só um benefício para os ex-reclusos, mas para a própria sociedade, que importa defender contra o perigo de reincidência que um ex-recluso sem trabalho e sem abrigo necessàriamente envolve.

(20) Starke, ob. cit., pág. 226. 
$\mathrm{E}$, decisivamente, tem de ter-se presente que a utilização das casas ou colônias de trabalho de transição só se impõe em último têrmo, isto é, quando não é possível reintegrar os reclusos na vida normal da sociedade.

Desta forma, o internamento será, em todo o caso, o menor de dois males.

c) Aceitando-se a necessidade da criação e funcionamento das casas ou colônias de trabalho de transição fica por resolver, ainda, o problema da sua organização.

Importa, por isso apontar ràpidamente alguns dos aspectos.

Ora, nesse domínio, há a dizer que tais estabelecimentos devem ser tanto quanto possivel administrados autônomamente, embora com o apoio e supervisão dos órgảos do Patronato ou da assistência social penitenciária, que os tenham criado e lhes prestem assistência econômica, moral e sanitária.

O internamento deverá ser voluntário e o número de beneficiários pequeno, porventura 12 a 60 , sendo de promover a criação de um ambiente de tipo familiar.

Não é de estabelecer qualquer preferência no internamento entre os delinqüentes, até para que tais instituições não enfermem dos prejuízos e preconceitos de sociedade que só agravam e facilitam a reincidência.

Dado o fim específico dêstes Homes de transição, ligado ao particular estado de necessidade dos ex-reclusos e ao perigo da sua reincidência, a êles, se deveria dar preferência. Nada, porém, impede que vagas existentes possam ser preenchidas por quaisquer indivíduos sem abrigo e sem trabalho, sobretudo se em particular perigo moral.

É de recomendar que as casas e colônias de transição funcionem relativamente, perto das cidades - para mais 
fàcilmente nelas se encontrar um emprêgo normal e que possuam "ateliers" e explorações industriais ou agrícolas: onde possa ser dado trabalho remunerado aos ex-reclusos.

Sem fixar prazos máximos de permanência, convém, todavia, que a organização dos lares de transição seja orientada de forma a dar aos ex-reclusos a consciência do caráter precário e provisório do internamento, e a pô-los ante a necessidade de se reintegrarem nos quadros normais da sociedade livre (21).

Claro que o que fica dito vale para os chamados Homes ou colônias de trabalho de transição. No que toca à organização de formas especiais de trabalho para ex-reclusos, por exemplo, de escritórios, de comissões e consignações, fomento de pequenos negócios, etc., o problema ter-se-á que pôr em equação com as condições particulares de especialização ou de cultura dos ex-reclusos e as possibilidades da sua aceitação pelos meios econômico e sociais das cidades ou lugares onde se pretendam instituir.

\section{IV}

Apontamos sumàriamente as necessidades que cumpre suprir e os meios que para tal importa utilizar em matéria de assistência prisional e post-prisional.

Mas cabe ainda perguntar: a quem deve cometer-se tal função? Aos indivíduos? Ao Estado? Ou a uns e outros conjuntamente?

1 - Durante muito tempo foi deixado como dissemos. aos particulares isolados ou em associações, a iniciativa e a realização dêsse tipo de assistência que se lhes impunha. como preceito religioso ou dever de caridade e humanidade.

A essa luz nasceram justamente as associações de patrocínio ou proteção aos reclusos e ex-reclusos sob a forma.

(21) Cfr. supra. 
de Patronato privado, que os poderes públicos se limitavam, quando muito, a promover, regular (22) e subsidiar (23).

E tal atitude do Estado em face do problema era corolário de uma certa concepção que se sufragava sôbre os fins do Estado em matéria de assistência e ainda sôbre o sentido e legitimidade da aplicação das penas.

Entendia-se, na verdade, não cumprir ao Estado realizar funções de assistência social já que tal excedia o mero fim legitimista de tutelar, permitindo o seu exercício, os direitos dos indivíduos tal como eram reconhecidos pela ordem jurídica.

A isso acrescia entender-se que uma tal intervenção prejudicaria ou faria concorrência à possibilidade de os particulares realizarem, êles próprios, como lhes impunha,

(22) Assim v. g. na Inglaterra logo pelo Peel's Gaol Act de 1823 e, depois, pelo Discharged Prisoners'Aid Act de 1862; na França, as Ordonnances de 1823, 1832 e 1847 e principalmente a lei de 1885 sôbre a liberdade condicional. Cfr. Bouzat, Aspect juridique de la sortie de prison in Journées d'Etudes des Aumoniers de prisons et du secours catholique, 1952, pág. 6; na Bélgica, os Comitès de Patronage foram em 1833 regulados, em 1848 reorganizados, e largamente estimulados por Jules LeJeune em 1888, cfr. ElSEghem, L'activité des comitès de patronage dans les questions pénitentiaires in La Prévention et la Répression de la Délinquance, XXIII e Semaine Sociale Universitaire, 1952, pág. 194. Uma mais larga atuação do Estado é já feita através dos chamados Conselhos do Patronato previstos no art. ${ }^{\circ} 149 .^{\circ}$ do Código Penal Italiano e na França pelos chamados Comitès post-pénaux criados por uma circular do Ministério da Justiça de Fevereiro de 1936. Cfr. ainda o art..$^{470^{\circ}}$ do Código Penal Suiço € o artigo de Clerc, Le lendemain de la peine in Verhandlugen des Schweizerischen Vereins für Straf-, Gefängniswesen und Schutzaufsicht, caderno 25, 1947, págs. 13 e segs.

(23) Sôbre o sistema do subsídio por cada preso entregue ao Patronato privado na Inglaterra, cfr. GRüNHut, ob. cit., e loc. cit.; Fox, ob. cit. e loc. cit. e Report cit. 
o seu dever moral e religioso, o apoio do semelhante na desgraça e no infortúnio (24).

Por outro lado, concebendo-se a pena como retribuição, como castigo correspondente ao mal do crime, uma vez executada e cumprida a sentença, estaria por parte do criminoso paga a sua dívida ao Estado como esgotado ficava pelo lado dêste o conteúdo do seu jus puniendi (25).

Por isso, a maior parte dos estudiosos do direito penitenciário no século passado, como ainda no primeiro quartel do atual, ensinavam que a assistência ao ex-reclusos não pertencia ao Estado mas era tão só questão e problema de caridade privada (26).

2 - Tais concepções estão hoje, porém, largamente ultrapassadas.

De todos os lados, se ocorre a afirmar que cabe aos poderes públicos, como seu fim essencial, garantir aos indivíduos a possibilidade de desenvolver perfeita e harmônicamente as virtualidades da sua personalidade (27).

Ora de tal idéia resulta, necessàriamente, que a assistência social constitui um dever para o Estado e um direito para os que se encontram colocados em necessidade que não podem por suas mãos completamente suprir.

Num passo de um seu notável parecer escrevia o Prof. Marcello Caetano (28): "O princípio de solidariedade en-

(24) Cfr. Beaufremon, Assistance Publique et Charité Privée, pág. 100 .

(25) GrÜNHUT, ob. cit., pág. 319.

(26) No sentido de considerar a assistência aos reclusos não como um dever do Estado, mas como uma mera obrigação privada e, portanto, atribuindo-a tão só a particulares e associações de $\mathrm{Pa}$ tronato privado, cfr. HolzeNdorfF. V. JAGEMANN-FuCHS, 1888; KRIEGSMANN cit., 1912; KroHne, Lehrbuch, § 56 e ainda Margarete Sommer, Fürsorge in Strafrecht, 1925.

(27) Duchin, $i$ problemi attuali dell'assistenza sociale, in Rivista Internazionale di Scienza Sociali, 1946, pág. 304.

(28) Publicado in Boletim de Assistência Social, 1943. 
tre todos os que fazem parte do mesmo grupo social impõe que a comunidade não abandone aquêles seus membros que lutem com necessidades" "Não é só portanto o amor do próximo por amor de Deus que num país cristão impõe o dever de assistência: a própria natureza social do homem o postula"

Desta forma, mesmo entendendo em têrmos puramente formais as relações entre o Estado e o condenado, no que toca à aplicação da pena e aos seus fins retribuitivos, certo é que, para além disso, cumpre àquele assistir aos ex-reclusos, sabido o especial estado de necessidade com que lutam.

Mas há ainda, no plano criminal, um aspecto particular a considerar: é que a situação de necessidade moral, econômica e, porventura, de saúde em que se encontra o exrecluso, pode, com o maior grau de probabilidade, fundamentar uma prognose sombria de criminalidade.

São as estatísticas indicando uma elevação assustadora da curva da reincidência que o demonstram sem sombra de dúvidas (29).

Ora, justamente, êste lado específico do problema não só lhe dá um lugar próprio, e o distingue, no quadro geral da assistência social, como explica que êle se transforme numa delicadíssima questão de prevenção da criminalidade de que o Estado não pode alhear-se, mas que antes lhe cumpre prementemente resolver (30).

(29) Cfr. sôbre as relações entre a falta de assistência aos reclusos e a reincidência Starke, ob. cit., e Grünhut, ob. cit., pág. 204.

(30) Cfr. Freudenthal, Entlassenenfürsorge, eine Pflicht der Allgemeinheit in zeitschrift f.d. Strafr., vol. 46, 1925, pág. 403 e segs.: "A assistência prisional e post-prisional é um dever do Estado", escreve, acrescentando: "O Estado que não apóia os reclusos, quando postos em liberdade, assemelha-se ao cirurgião que deixa aberto o ventre que operou em vez de curar as feridas". Cfr. nesse sentido Grünhut, loc. cit., pág. 317 e Fox, ob. cit., pág. 254. 
3 - Tanto mais que tal corresponde ao moderno sentido da política criminal e das reações e instituições novas. que ela propõe e sugere.

Tem-se vindo na verdade, de há muito tempo, a ensinar que o direito criminal tende a ser o direito preventivo, de defesa social (31).

Por isso se proclama a necessidade de rever tôda a aparelhagem dêsse ramo da or'dem jurídica alterando-o ou integrando-o com tudo o que lhe seja mister para realizar essa função.

A) Ora, a primeira projeção de tal idéia foi, como se disse, a de reconsiderar o próprio sentido da execução da pena de prisão.

Assim, para além da função de castigo, importava atribuir-lhe um papel regenerador e de readaptação do criminoso à vida social, o que se procurava alcançar, fundamentalmente, através de uma reorganização do trabalho. prisional.

Porque a readaptação não é, porém, súbita, mas supõe etapas sucessivas, lançou-se mão da idéia de uma execução. da pena por períodos, agruparam-se os delinqüentes e os. estabelecimentos prisionais em comunidades cada vez mais semelhantes às da vida social, procurando fortalecer nos internados o sentimento de autonomia e de responsabilidade. A êste pensamento correspondem os chamados períodos de confiança, os estabelecimentos abertos, o regime de semi-liberdade (32), a sentença indeterminada, a liberdade condicional, etc.

(31) Cfr. MARC ANCEL, La Défense Social.

(32) Sobre o Home Leave Scheme cfr. Fox, Note sur les developpements de la liberation conditionnelle et de la readaptation sociale post-pénitentiaire dans le Royaume-Uni, documento de trabalho n. 4 (29 de Junho de 1954) apresentado ao "Groupe Régional Consultatif Européen dans le domaine de la Prévention du crime et du traitement des délinquants", das Nações Unidas, pág. 4. 
B) Ainda, porém, mesmo informada dêste espírito e desta elasticidade, não logrou, como dissemos, a pena de prisão que no século XIX tendia a transformar-se em meio repressivo quase exclusivo nem assim a pena de prisão logrou, dizíamos, - assegurar o seu predomínio.

E se não foi nem porventura poderá ser nunca totalmente abolida, se não entrou em total falência, viu que por todos os lados, se exigia que reduzisse o seu domínio de aplicação ao menor número de casos possível.

Desta forma, o programa de fazer despovoar as prisões, de diminuir tanto quanto possível o número de reclusos nos estabelecimentos prisionais, domina hoje os horizontes novos da política criminal (33).

Assim, não só se aconselha o uso cada vez mais freqüente da liberdade condicional como há manifesta tendência para não aplicar a prisão, sobretudo quando se trate de criminosos primários e a sua duração seja curta.

A esta luz se desenvolveram ainda os chamados institutos da pena suspensa e da probation hoje tão largamente utilizado e estudado no estrangeiro, em que, respectivamente, o Estado renuncia à execução da pena de prisão, ou à própria condenação, desde que o criminoso prometa esforçar-se por seguir, em liberdade, uma vida honesta e afirme a sua vontade de se regenerar e readaptar à vida social (34).

(33) “Abbau der Freiheitsstrafe, Vermehrung der Fürsorge!", "Diminuam-se as penas de prisão e aumente-se a assistência!" escreve STARKe, ob. cit., pág. 206.

(34) Sôbre êstes institutos cfr. BERGER, Le système de probation anglais et le sursis continental, 1953, e Probation and Related Measures, 1951; Practical results and financial aspects of adult probation in selected countries, 1954; Parole and after-care, 1954; European Seminar on Probation, 1954, publicações das Nações Unidas e os Relatórios de GRÜNHUt e de Simson sôbre pena suspensa (Bedingte Verurteilung) in Zeitschrift f.d.g. Dtrafr., 1952, vol. 64, págs. 127 e segs. 
4. - E não se pense - importa notar - que tôdas estas perspectivas são puro resultado ou só conciliáveis com um direito criminal preventivo ou de defesa social, de tipo naturalístico.

Nem aliás se tornaria possível, em último têrmo, despojar êste ramo do direito do seu sentido ético. Mais: êste mesmo aspecto especifica, caracteriza, essencialmente, o seu domínio.

Só que a própria idéia da retribuição se estrutura hoje de forma a referir-se não só ao fato, mas ao modo de ser perigoso do delinqüente, à culpa na sua formação da personalidade. E isto não só enquanto justifica um castigo reeducativo de maior ou menor duração e intensidade, mas ainda enquanto o plano ético em que se coloca permite renunciar a êle, em nome da prevalência de outros valores morais como é o da conveniente realização da personalidade do delinqüente e, portanto, pode admitir nos seus quadros a pena suspensa, a probation, a liberdade condicional, a sentença indeterminada, etc., etc.

5 - De qualquer forma, porém, todos êstes institutos que procuram reduzir o domínio de aplicação das penas privativas de liberdade, fazendo no fundo um apêlo ao sentimento de auto-responsabilidade, pretendendo dar ao criminoso ainda uma última chance e oportunidade para em liberdade se adaptar às exigências da vida social, todos êstes institutos não podem deixar, nem deixam, de tomar em conta a sítuação particularmente difícil em que êle se encontra.

Nem a obra pedagógica que através dêles se quer realizar seria completa e deixaria dever o seu êxito comprometido, se não ajudasse a planear a vida futura do delinqüente, impondo-lhe o respeito de um conjunto de obrigações mais ou menos rígidas ou mais ou menos elásticas, julgadas no caso favoráveis à readaptação (35).

(35) Cfr. nota anterior. 
Daí, por exemplo, que lhe imponham o dever de se afastar do meio em que viveu antes da infração, quando êle se considere criminógeno; lhe interditem a freqüência de lugares ou o contacto com certo tipo de pessoas de moralidade e costumes duvidosos; lhes proiba o uso de bebidas alcoólicas; thes comandem a obrigação de trabalhar, sobretudo, quando a etilogia do crime esteja ligada à ociosidade ou vagabundagem; lhes exijam que se submetam a tratamentos médicos de natureza geral ou específica, por exemplo, a cura psicoterápica ou psicoanalítica, com vista a superar e a vencer certos complexos da personalidade que póssam ter estado na origem da atividade criminosa ou que nela se revelem.

Em certos casos, quando o próprio meio familiar não é aconselhável, será ainda de impor a obrigação de viver durante algum tempo num lar ou colônia de trabalho de modo a tornar mais fácil a recuperação da sua personalidade. E aqui pode ainda ser vantajosa a chamada "transplantação" para terras ou lugares longínquos dos da prática do crime, aproveitando as próprias províncias ultramarinas, ainda que o pensamento tenha sido tão mal compreendido e por vêzes tão primária e simplesmente condenado (36).

6 -- Em tudo isto, porém, precisa o delinqüente de ser vigiado. Mas não só isso. É mister que seja externamente amparado e de certo modo tutelado.

Tem de considerar-se que o homem, além da vontade livre que o auto-modela, se move num certo condicionalismo biológico e social que fortemente pesa nas suas determinações. E se é legítimo, em último têrmo, responsabilizá-lo pelo que êle é ou venha a ser, importa por humanidade e interêsse da prevenção criminal dar-lhe, embora discretamente auxílio e proteção. $O$ delinqüente pôsto em líberdade condicional, em probation, precisa, em suma, como

(36) Cfr. Brandstatter, ob. cit. 
resume a fórmula inglêsa, de ser "aconselhado, ajudado e tratado como amigo"

É mister que alguém se ocupe dêle, lhe ajude a encontrar trabalho, porventura a constituir um lar, capte a sua confiança, lhe mostre claramente a natureza dos deveres que como homem livre se lhe impõem de se integrar na vida social, bem como lhe faça representar e medir as conseqüências quando tente furtar-se a tais obrigações.

Trata-se no fundo de inculcar ao violador da lei uma nova concepção da vida, robustecer a sua confiança em si, fortificar o sentimento de responsabilidade pessoal (37).

$\mathrm{O}$ que não se consegue através dos métodos clássicos e desacreditados de bons conselhos e de boas palavras, mas mediante uma atuação apropriada a cada caso particular, e tendo na sua base cuidadosos inquéritos, através de um (Casework) orientado pela ciência psicológica que procure abrir e degelar o delinqüente, descobrir os complexos particulares, os conflitos sociais, econômicos ou mesmo de saúde, sobretudo quando de natureza sexual, que o arrastam ao crime (38). Há que procurar depois removê-los ou, se não é possível, ajudar a desenvolver contra fôrças que permitam superá-los no quadro total da personalidade. Para usar imagem de Kretschmer, trata-se neste caso de conseguir elevar o nível da corrente do eu de forma a que, a despeito das pedras e dos escolhos que permaneçam no seu fundo, se torne possível a navegação na vida, isto é, se possa atuar de harmonia com as exigências sociais.

(37) Cfr. Berger, ob. cit., pág. 81.

(38) Cfr. Mme. Bray, le service social pénitentiaire in la Prévention et la Képression cit., pág. 194 e largamente Paskell, probation case work: basic principles and methods in European Seminar cit., pág. 87 e ainda nesse lugar CARROLL, personal relationships in the rehabilitation of persons on probation, pág. 107 . Cfr. ainda a conferência do Prof. Beleza dos SANtos, algumas considerações sôbre o serviço social (1931), ns. 3 e 4 . 
Tudo isto, porém, exige um alto grau de experiência social, de conhecimentos psicológicos, psicopatológicos, de sociologia e de criminologia e, por sôbre tudo isto, de intuição dos problemas humanos que não pode ensinar-se.

Impõe uma energia que, não se podendo transformar em coação, não deve enfraquecer a ponto de fazer perder tôda a autoridade e que, não deixando de ser vigilância, se apóia fundamentalmente num plano de mútua colaboração e de confiança.

Funções tão complexas não podem, porém, mostra-o a experiência, ser realizadas por um simples particular, embora dotado da melhor boa vontade, zêlo religioso ou sentido de devotamento. "Perante os problemas postos pela política criminal moderna", escreve Berger (39), "os grandes fervores de interêsse filantrópico se não forem apoiados por uma sólida formação técnica social e criminológica são inoperantes. $\mathrm{E}$ isto é especialmente válido no que toca a atividades que se caracterizam pela sua função reformadora e pedagógica."

7 - E tudo isto impôs aos sistemas legislativos que confiassem a tutela e vigilância de tais delinqüentes, beneficiando de liberdade ao abrigo dos institutos apontados, a funcionários próprios, verdadeiros trabalhadores sociais, com forte especialização nos problemas de prevenção criminal, isto é, a assistentes sociais penitenciários (40).

(39) Cfr. Berger, ob. cit., pág. 63.

(40) Cfr. Parole and after-care cit., pág. 10 e segs.; BERGER cit., especialmente pág. 63 e segs. e Younghusband, Probation personnel in European Seminar cit., pág. 121 e segs. que descreve vários períodos na história da supervisão da Probation: um primeiro em que é levada a cabo por voluntários, depois (1876) por voluntários de sociedades missionárias em ligação com os tribunais, em 1907 por funcionários assalariados indicados por magistrados, terminando pela obrigatoriedade da entrega da supervisão a probation officers. Veja ainda o estudo de GRAVEN, Le sens du sursis conditionnel et sons developpement, in Revue Penale Suisse, 1954, pág: 261 e segs. 
O que, naturalmente, por sua vez, envolve os mais complexos problemas de seleção, preparação, disciplina, retribuição, limites do esfốrço a exigir a êsses funcionários (probation officers) a que, modernamente, nos meios criminalistas internacionais se tem dado a maior atenção.

Mas importa prementemente resolvê-los com tôdas as conseqüências que isso importe, como v.g. a criação de Escolas Superiores de ciências auxiliares do direito criminal, se não se quer renunciar a todos os benefícios que a ciência e experiência já hoje mostram ligados à adoção dos apontados institutos complementares e subștitưtivos das penas preventivas de liberdade (41).

8 - Em face disto pergunta-se: se é mister organizar os quadros de assistentes sociais penitenciários como pedra angular do funcionamento da probation, da pena suspensa, da liberdade condicional, etc., por que os não aproveitar ou alargar a sua função à realização da assistência prisional e post-prisional?

Também neste domínio, como repetidamente se acentuou, a preparação e reintegração dos delinqüentes na sociedade é particularmente difícil; também em tal matéria há problemas morais econômicos e de saúde que o ex-recluso dificilmente pode resolver só por si; também nesta zona a benificiência privada não garante a continuidade, a permanência e a universalidade de assistência de que êles necessitam; também aqui as melhores boas vontades, sem conveniente preparação podem trazer mais prejuízos que benefícios (42).

A tudo isto acresce como dissemos que os perigos ligados à particular situação dos ex-reclusos libertados definitivamente constitui um momentoso problema de prevenção da reincidência e, portanto, da criminalidade que cumpre ao Estado resolver.

(41) Cfr. por todos Berger, ob. cit., págs. 67 e segs.

(42) Cfr. Simson, loc. cit, pág. 152. 
$\mathrm{E}$ eis porque a mais moderna tendência da política criminal consagrada, por exemplo, na legislação francesa de 1952 seja no sentido de responder afirmativamente à questão acima posta; integrando a assistência prisional e post-prisional no quadro de funções dos serviços sociais penitenciários oficiais, ao menos, com o fim de a estruturar, coordenar e garantir (43).

9 - Há, todavia, um problema a pôr aqui: será legítimo impor assistência, contra a sua vontade, a quem totalmente pagou a sua dívida ao Estado cumprindo integralmente a pena a que foi condenado e saindo em liberdade definitiva?

Certos sistemas legislativos, como, por exemplo, o francês (44), determinam que a assistência post-prisional aos reclusos postos em liberdade definitiva exige que êstes nela consintam beneficia non obtrunduntur.

Parece, porém, que esta posição esquece, justamente, que o ex-recluso, embora pôsto em liberdade definitiva segundo os critérios clássicos, pode encontrar-se num estado de necessidade que comporte uma forte probalidade de reincidência.

Ora, então, parece legítimo que o Estado imponha assistência em nome do interêsse público na prevenção da criminalidade, ou o mesmo é que dizer, desde que o ex-

(43) Cfr. Starke, loc. cit., pág. 213. Uma larga realização desta idéia foi levada a cabo na França através da lei de 1 de Abril de 1952 e da circular do Ministério da Justiça de 31 de Maio de 1952, publicada na Revue pénitentiaire et de Droit Pénal, 1952, pág. 721 e seg. Veja sôbre o problema ainda o Relatório do Comité misto nomeado na Inglaterra em 1951 com elementos da Comissão das Prisões e da National Association of Discharged Prisoners'Aid Societies, presidido por MAXwell e publicado oficialmente em 1953 a que se refere Fox no documento de trabalho cit. apresentado ao grupo regional europeu das Nações Unidas, documento n. ${ }^{4}$.

(44) Cfr. o art. $.^{\circ} 2 .^{\circ}$ da citada lei de 31 de Maio de 1952: "L'assistence des libérés définitifs ne peut être organisée que si ceux-et comité". 
-recluso que a recuse não demonstre que tal não constitui um perigo para a ordem jurídica criminal.

O problema é, aliás, paralelo ao do repúdio em geral da assistência social. E também aqui, muitos, como Leclère, ensinam que o direito de recusar auxílio social só é de reconhecer quando aquêle que o exerce pode mostrar que sem tal auxílio não se torna um perigo para a sociedade (45).

E, como é evidente, a consideração tem particular acuidade quando se trate de perigosidade criminal (46).

10 - Simplesmente, uma vez admitida, como organizar jurìdicamente esta assistência penitenciária obrigatória?

Parece que tudo se poderá resolver utilizando a idéia apresentada por Dupréel no XII Congresso Penal de Haia no seu Relatório Geral, essencialmente aprovado na resolução final, segundo a qual é desejável, em todos os casos, que antes do fim da pena a cumprir pelo condenado, sejam tomadas medidas para assegurar um regresso progressivo à vida social normal. Isto conduzirá conforme os casos a um regime de pré-liberdade a criar no seio dos estabelecimentos ou a que se conceda a liberdade a título de ensaio, sob contrôle eficaz.

Desta forma, sempre que se mostre que o recluso precisa de ser aconselhado e orientado antes da sua integração total na vida livre, a sua libertação deveria ser sempre ordenada sob a forma condicional.

E isto, como aliás no Congresso de Haia já se considerou (47), implica o funcionamento da assistência com caráter obrigatório e oficial desde o início da execução da

(45) Apud Beaufreton, ob. cit., pág. 29, nota 1.

(46) Cfr. StaRKe, loc. cit., pág. 209.

(47) Actes du Douzième Congrés Pénal et Pénitentiaire International (1950), vol. V, pág. 181 e vol. I, pág. 633. 
prisão, não só para tornar possível um serviço social post-prisional útil, mas ainda para fornecer à entidade, a quem compete decidir sob a forma da libertação, os necessários elementos familiares, sociais e econômicos.

\section{V}

Reconhecendo-se assim que cumpre ao Estado o dever de organizar e fazer funcionar uma assistência prisional e post-prisional, integrada, em princípio, no serviço social penitenciário, isso não significa, de nenhum modo, que se deva afastar e repudiar o auxílio e iniciativa dos particulares ou das associações privadas.

$\mathrm{Na}$ verdade a colaboração dêstes elementos com os órgãos oficiais a quem cumpre realizar a assistência prisional e post-prisional permite atenuar ou diminuir o caráter se não policial pelo menos suspeito, que, a despeito de todos os esforços que para evitar se façam (v.g. autonomisar disciplinarmente os assistentes sociais penitenciários relativamente à direção dos estabelecimentos prisionais), ela possa ter quando levada a cabo exclusivamente por funcionários (48).

E aqui é de lembrar o exemplo das visitas aos presos. Os visitadores exercendo uma missão que o cristianismo indicou entre as obras de caridade dão aos reclusos um apoio moral insubstituível.

(48) StARKe, ob. cit., pág. 217. A assistência penitenciária, dado o seu carácter específico de prevenção criminal, é ainda um problema de administração da justiça e, portanto, especial, em relação à assistência social comum. Importa, todavia, distinguí-la da liberdade vigiada. Sôbre a função da assistência prisional e a sua distinção da antiga vigilância policial cfr. Foltrin, Bedeutung und Anwendungsgebiet der Schutzaufsicht gegenüber Erwachsenen, in Monatsschrift für Kriminalpsychologie und Strafrechtsreform, 1927, pág. 289 e segs. Cfr. ainda o citado Repport. Employment, 1935. pag. 62 . 
Eles fazem entrar na cadeia o ar fresco da sociedade livre do exterior. São homens de uma sociedade livre, inteiramente desligados de funções oficiais, que de nenhuma maneira representam o Estado titular da repressão, que procurando os presos mostram, o seu interêsse por êles, pela sua família, pelos seus problemas, guiados e determinados tão só por um dever de caridade, filantropia ou solidariedade humana (49).

$A$ isto acrescente-se que se é certo que, em princípio, a vigilância e tutela dos presos postos em liberdade deve cometer-se a assistentes sociais penitenciários que têm especial preparação técnica, meios e tempo de que não dispõé normalmente o particular, mesmo se delegado de uma associação ou Patronato privado, verdade é também que nem sempre tais deficiências se verificam e que há por vêzes particulares que juntam um sentimento de humanidade, devotamento e experiência da vida a uma cultura, até, por vêzes, especializada em matéria de prevenção criminal, cujos serviços e préstimos de nenhuma forma convém recusar.

Por outro lado, pelo menos em casos não muito difíceis, a própria boa vontade de servir os outros e de salvar alguém prestes a recair no mal pode largamente suprir a falta de preparação técnica e profissional.

Considere-se ainda que as relações da vida social configuram-se por vêzes de forma a que um assistente privado ou voluntário pode estar em especiais condições para vigiar e dar apoio construtivo a certos reclusos postos em liberdade.

$\mathrm{E}$ acima de tudo deve ter-se sempre presente que os esforços dos assistentes penitenciários serão vãos se não puderem utilizar as facilidades concedidas por instituições ou entidades privadas, como hospitais, clinicas, ordens re-

(49) Cfr. sôbre isto a regulamentação dada na França pela circular de 27 de Julho de 1952 publicada na Revue Pénitentiair et de Droit Penal, 1952, págs. 730 e segs. Veja ainda Krebs, Radbruchfestschrift, 1948, pág. 174 e segs. 
ligiosas, associações, emprêsas, sociedades que empreguem trabalho è se de uma maneira geral, não puderem contar com tôda as formas de beneficência privada e até com a compreensão de tôda a sociedade (50).

Importa, assim, aproveitar tôdas as vocações, tôdas as boas vontade, tôdas as dedicações possíveis neste esfôrço tão particularmente difícil.

Nem seria possivel ao Estado, sòmente através dos seus serviços oficiais, conseguir, não só os meios financeiros, mas ainda e sobretudo, criar o clima social, que permita levar a bom têrmo a obra de recuperação dos criminosos; essa obra que, na famosa frase de Channing (52), "é mais bela, que fazer levantar os mortos dos seus túmulos".

\section{Conclusões}

1 - Na medida em que, em direito criminal, não é possível deixar de recorrer-se a penas privativas de liberdade, a aplicação destas deve ser integrada por uma assistência, tendente a remover o especial estado de necessidade moral, econômico e sanitário que dela resulta para o delinqüente que as sofre, como para a respectiva família, e isto, quer durante a reclusão, quer no período que se lhe segue.

(50) Cfr. também Starke cit., Grünhut cit., pág. 316.

(51) Cfr. Practical resultes and financial aspects of adult probation, cit., onde se mostra estatìsticamente que a assistência social não fica mais cara do que o tratamento intra-muros. Cfr. ainda a êste propósito Starke que põe $\epsilon \mathrm{m}$ relevo o mesmo pensamento citando um dos pontos do apêlo da Sociedade Prisional de Wakefield: "Remember! That every prisoner restored to society and selfrespect is a gain to the nation. It costa £ 100 per annum to: keep a man in prison", loc. cit., pág. 206.

(52) Apud Buchs, Comment peut-on rendre le Patronage des - Détenus Libérés plus populaire? in Verhandlungen des Schweizerischen Veneins cit., pág. 70. 
2 - Em todos os casos, esta assistência prisional ce post-prisional deve ser precedida de inquéritos e orientada por forma a estudar e resolver concretamente cada caso individual (Casework).

3 - No que diz respeito à função econômica da assistência post-prisional importa, fundamentalmente, assegurar ao recluso, quando seja pôsto em liberdade, o que supõe a resolução do problema num momento anterior trabalho estável e imediato. Quando isso, desde logo, se não possa conseguir nos quadros normais da sociedade, torna-se forçoso recorrer aos chamados Homes, colônías de trabalho ou escritórios, de transição, para ex-reclusos.

4 - A assistência prisional e post-prisional, entregue, tradicionalmente, à iniciativa e Patronato privado, deve atribuir-se natureza pública e considerar-se função do Estado.

5 - Dado o particular aspecto preventivo do crime de tal tipo de assistência, há que distinguí-la da assistência social comum, reconhecendo-a instituição completamentar do direito criminal.

6 - A assistência deve iniciar-se imediatamente a seguir à entrada do delinqüente na prisão.

7 - Mostra-se forçoso selecionar preparar oficial e especialmente - e para tal sugere-se a criação pelo Estado de escolas de ciências auxiliares do direito criminal — assistentes sociais penitenciários, destinados a vigiar e apoiar construtivamente os delinqüentes em liberdade, que beneficiem de institutos como os da probation, pena suspensa, liberdade condicional e semelhantes, Desta forma, dada a unidade dos problemas; devem-se alargar o quadro e as funções dos serviços sociais penitenciários à realização da assistência prisional e post-prisional, ao menos, com o fim de a estruturar, coordenar e garantir.

8 - A assistência post-prisional deve ser obrigatória para todos os ex-reclusos, salvo quando se mostra que êles dela não carecem. O meio técnico-jurídico de se conseguir 
-esta obrigatoriedade, como regra, seria o de se legislar no sentido de que, sempre que fòr necessário para conseguir aquêle fim, a libertação de qualquer recluso poderia ter lugar sob a forma condicional.

9 - O reconhecimento de que cumpre ao Estado o dever de organizar oficialmente, assistência prisional e post-prisional, integrando-a nos serviços sociais penitenciários, nâo significa que se deva repudiar e recusar o auxílio dos particulares e das associações de Patronato privado. Êste é, especialmente, de acolher no que toca ao problema das visitas aos presos. Além disso, em certos casos, menos difíceis, deve permitir-se a colaboração de assistentes privados voluntários para vigiar e apoiar construtivamente ex-reclusos. Por outro lado, os serviços sociais e penitenciários do Estado não podem deixar de socorrer-se das facilidades e apoio concedidos pelos particulares e, sobretudo, não podem prescindir da compreensão, que importa proamover, da sociedade em geral. 